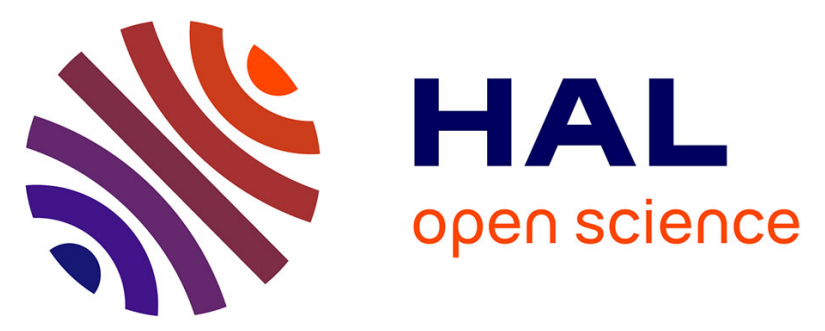

\title{
Marketing strategies to self-sustainability of autochthonous swine breeds from different EU regions: a mixed approach using the World Café technique and the Analytical Hierarchy Process
}

Evelyn Rivera-Toapanta, Zein Kallas, Meta Čandek-Potokar, Joel Gonzalez, Marta Gil, Elsa Varela, Justine Faure, Marija Cerjak, Tomažin Urška, Chiara

Aquilani, et al.

\section{- To cite this version:}

Evelyn Rivera-Toapanta, Zein Kallas, Meta Čandek-Potokar, Joel Gonzalez, Marta Gil, et al.. Marketing strategies to self-sustainability of autochthonous swine breeds from different EU regions: a mixed approach using the World Café technique and the Analytical Hierarchy Process. Renewable Agriculture and Food Systems, 2022, 37 (1), pp.92-102. 10.1017/s1742170521000363 hal-03336987

\section{HAL Id: hal-03336987 https://hal.science/hal-03336987}

Submitted on 7 Sep 2021

HAL is a multi-disciplinary open access archive for the deposit and dissemination of scientific research documents, whether they are published or not. The documents may come from teaching and research institutions in France or abroad, or from public or private research centers.
L'archive ouverte pluridisciplinaire HAL, est destinée au dépôt et à la diffusion de documents scientifiques de niveau recherche, publiés ou non, émanant des établissements d'enseignement et de recherche français ou étrangers, des laboratoires publics ou privés. 
Renewable Agriculture and

Food Systems

\section{cambridge.org/raf}

\section{Research Paper}

Cite this article: Rivera-Toapanta E et al (2021). Marketing strategies to selfsustainability of autochthonous swine breeds from different EU regions: a mixed approach using the World Café technique and the Analytical Hierarchy Process. Renewable Agriculture and Food Systems 1-11. https:// doi.org/10.1017/S1742170521000363

Received: 27 August 2020

Revised: 29 January 2021

Accepted: 16 July 2021

\section{Keywords:}

Analytical hierarchy process; autochthonous swine breeds; local meat products; marketing; PDO; PGI products; World Café Focus Group

\section{Author for correspondence:}

Evelyn Rivera-Toapanta,

E-mail: evelyn.rivera@irta.cat
Marketing strategies to self-sustainability of autochthonous swine breeds from different EU regions: a mixed approach using the World Café technique and the Analytical Hierarchy Process

\author{
Evelyn Rivera-Toapanta ${ }^{1}$ (D), Zein Kallas ${ }^{2,3}$ (D), Meta Čandek-Potokar ${ }^{4}$, \\ Joel Gonzalez ${ }^{1}$, Marta Gil ${ }^{1}$, Elsa Varela ${ }^{1,2}$, Justine Faure ${ }^{5}$, Marija Cerjak ${ }^{6}$, \\ Tomažin Urška ${ }^{4}$, Chiara Aquilani ${ }^{7}$, Bénédicte Lebret ${ }^{5}$, Danijel Karolyi ${ }^{6}$, \\ Carolina Pugliese ${ }^{7}$ and José Maria Gil ${ }^{2,3}$
}

${ }^{1}$ IRTA, Food Industries, Finca Camps i Armet,s/n 17121 Monells, Spain; ${ }^{2}$ CREDA-UPC-IRTA, Centre for Agro-food Economy \& Development, 08860 Castelldefels, Spain; ${ }^{3}$ Department of Agri-Food and Biotechnology Engineering, UPC, Universitat Politècnica de Catalunya, Barcelona School of Agri-Food and Biosystems Engineering, Barcelona, Spain; ${ }^{4} \mathrm{KIS}$, Kmetijski Inštitut Slovenije, Agricultural Institute of Slovenia, Hacquetova ulica 17, 1000 Ljubljana, Slovenia; ${ }^{5}$ PEGASE, INRAE, Institut Agro, 35590 Saint Gilles, France; ${ }^{6}$ UNIZG, University of Zagreb Faculty of Agriculture, Svetošimunska Cesta 25, 10000 Zagreb, Croatia and ${ }^{7}$ Department of Agriculture, Food, Environment and Forestry (DAGRI), Section of Animal Sciences, UNIFI, Universita degli Studi di Firenze, Via delle Cascine, 5-50144 Firenze, Italy

\begin{abstract}
Extensive and semi-extensive production based on local swine breeds such as Majorcan Black Pig, Cinta Senese, Gascon, Krškopolje and Turopolje is becoming extremely rare and on the verge of disappearing in Europe. In this context, the main aim of this study was to assess the potential feasibility of marketing strategies to act as guidelines for stakeholders along the supply chain to create and improve added value and match market demands. The sustainability of five production systems was evaluated together with 60 stakeholders representing five local swine breeds, using a World Café (WC) method combined with an Analytical Hierarchical Process (AHP). The results showed that the proposed strategies could differ slightly depending on each system, while the product strategy was a common marketing priority for most of the stakeholders and represented all the systems evaluated. Diversifying production toward quality, innovative products, enhanced standardization, and quality labeling or seals of guarantee, such as the protected geographical indication or the protected designation of origin, would contribute to the sustainability of these chains. Advertising the storytelling of the meat products and emphasizing their healthier properties were also considered as positive strategies. To this effect, promotion should involve improving knowledge of the local systems and raising the profile of the meat products via public relations (networks, web pages, food and gastronomic events, workshops and so on) in the Hotels, Restaurants and Catering (HORECA) sector, stores selling top-quality products and local food shops. Better showcasing of these products and keeping the price in the premium segment would indirectly help the primary sector. By way of conclusion, other more developed local swine systems could be strong competitors, hence it is extremely important to effectively identify and trace all autochthonous swine breed products throughout the production chain. Furthermore, the entire chain must place greater emphasis on grazing (extensive or semi-extensive), the origin of the swine and their meat products. However, of utmost importance is cooperation between farms, firms and institutions.
\end{abstract}

\section{Introduction}

The sustainable conservation of autochthonous swine breeds and local chains could be partly achieved by highlighting the high-quality intrinsic and extrinsic properties of the products derived from them and by promoting their consumption by specific market niches (Vitale et al., 2020). Moreover, traditional food products constitute an important element of European culture, identity and heritage (Ilbery and Kneafsey, 1999; Lebret et al., 2018), and are increasingly being proposed as a way to raise societal awareness of rural landscapes (Soy-Massoni et al., 2019). However, innovation in traditional products may face some challenges related to the likely contested understanding of these concepts (Guerrero et al., 2012), making it particularly difficult to develop innovations acceptable to consumers. Improving breed profitability through niche markets and increased added-value products [i.e., healthier nutritional properties (Romanzin et al., 2013)] , ensuring a return to breed populations high enough to 


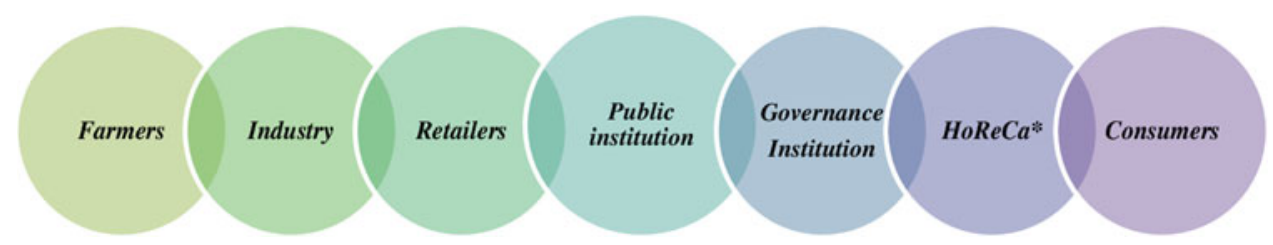

Fig. 1. Stakeholders' type included in the focus groups. *: Hotels, Restaurants, and Catering.

maintain adequate genetic diversity and hence safeguard breed survival (Bozzi and Crovetti, 2013). Varga et al. (2016) reported that swine grazing had almost disappeared in Europe by the 1970s. In this context, research on market opportunities and analysis of consumer preferences and the factors affecting sustainability will be a key strategy. This will focus on the renewability and resilience, thereby aiming to regenerate the social, environmental and economic impacts (Swisher et al., 2018).

Some studies (Brown, 2003; Conner et al., 2009) have concluded that local foods are related to spatial proximity, freshness and higher sensorial quality, but for the authors, the most important 'local' promotion message may be 'Grown in' and the name of the region or city rather than the distance (from food production to consumers). Howard (2006) also found that consumers prefer to obtain information that includes the word 'local' on labels or in brochures rather than through direct interaction with the seller. Unlike intensive production, the swine in the five local systems studied are raised outdoors/extensively and so depend on the resources of their natural surroundings, defined as grazing habitats in the review carried out by Varga et al. (2016). Moreover, consumers perceive pasture-raised products as healthy, natural and environmentally friendly and some of them are willing to pay a premium price for pasture-raised meat-based products (Font-i-Furnols and Guerrero, 2014; Stampa et al., 2020). These Localized Agro-Food Systems also open new perspectives for territorial and regional development projects (Muchnik et al., 2008).

In this context, research on market opportunities, analysis of consumer preferences and the factors affecting their acceptance of different types of product is a crucial strategy to support traditional autochthonous swine breeds and promote their development. Effective promotional and marketing strategies have been defined for potential markets through developing the role of location in promoting more advantageous sales methods for farmers in nontraditional distribution channels (short distribution channels, direct sales). The present study has a twofold objective: first, to carry out a Strengths, Weaknesses, Opportunities and Threats (SWOT) analysis on five European autochthonous swine breed production systems to identify the critical points of the adopted marketing channels; and secondly, to identify appropriate marketing strategies for each study case to provide stakeholders along the supply chain with guidelines for enhancing added-value products and for developing direct marketing alternatives to analyze viability and feasibility.

\section{Material and methods}

The aim of the TREASURE H2020 project (Horizon 2020 Programme, 2015) was to improve the conservation status of 20 European autochthonous swine breeds through innovative strategies that included untapped new market options for these breeds (Čandek-Potokar and Nieto Linan, 2019). Five of them and their related value chains with contrasting properties in terms of level of development and organization and representing different EU regions were considered for a study of their marketing strategies (Karolyi et al., 2019; Lukač et al., 2019; Mercat et al., 2019; Pugliese et al., 2019; Tibau et al., 2019). The reason for including the untapped breed is that it was mandatory in the UE call for proposals (Research and Innovation Action, Grant agreement $N^{\circ}$ : 634476).

\section{Experimental design}

We followed a mixed-method research methodology and applied a joint qualitative and quantitative approach (Weible et al., 2016), carrying out focus group (FG) sessions using the World Café (WC) method and the Analytical Hierarchical Process (AHP) because of their specific strengths. Five FG sessions, one for each of the case studies, were performed between May and July 2018 in Louey (Hautes-Pyrénées-France), Florence (TuscanyItaly), Palma de Mallorca (Spain), Ljubljana (Slovenia) and Zagreb (Turopolje region-Croatia).

Each FG included at least 12 stakeholders from each local system, with a balanced representation of the five stages in the value chain (Fig. 1). The suggested shares of stakeholder profiles in the FG were three farmers, two processors, a civil servant/policy maker working in public administration (either regional or local), a representative related to the governance of the quality seal [protected designation of origin (PDO)/protected geographical indication (PGI)], if applicable, a traditional store retailer, a supermarket retailer, a food service representative (restaurants) and two people working in consumer associations $(n=60$ in total). The final number of participants in each profile was adapted slightly in each case study, depending on the characteristics of the corresponding supply chain. The WC was applied to gain insights into two sets of attributes in each case study: (a) the SWOT matrix and (b) the most suitable marketing strategies based on the $4 \mathrm{Ps}$ of marketing (Product, Price, Place and Promotion) for the breed production system. The WC is a structured conversational process intended to facilitate open and intimate discussions, and share ideas within a larger group to obtain collective consensus decisions.

All the participants were balanced (in terms of number and also the type of stakeholder in the chain) and separated into four thematic tables (groups for the discussion) with one moderator per table. Each table was designed to gather information about one of the four components of the SWOT analysis. For 10-12 min, the participants at each table expressed their thoughts about the SWOT regarding the pertinent swine production systems and their meat products. Further, the groups agreed among themselves on a list of the most relevant items, along with the moderator. Afterwards, they moved to another table, ensuring that no two participants coincided at two consecutive tables. This rotation was repeated until all the stakeholders had participated at all the four tables. 


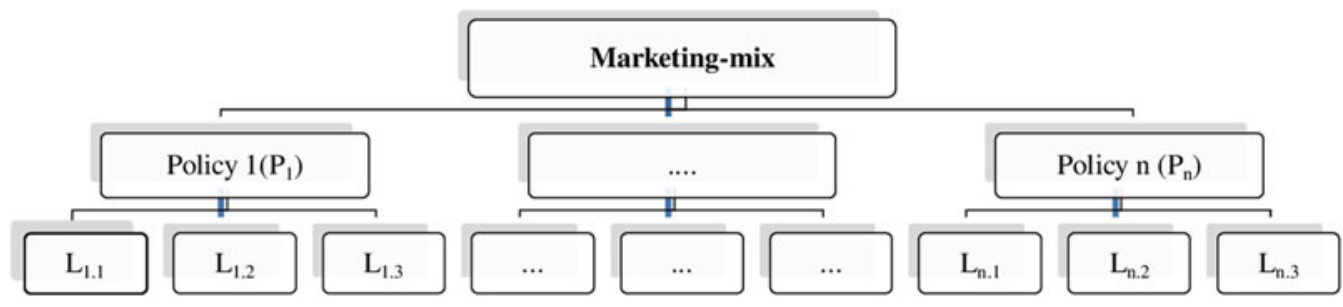

Fig. 2. Hierarchical structure used to value the best policy for the untapped swine breeds.

The most relevant items raised in terms of SWOT at each discussion table were then voted in a plenary session. Each participant chose three prominent items depending on their choice, and further ranked them to assign three, two or one point based on the rank. In a second step, participants addressed the marketing strategies (4Ps). The same procedure was then followed to obtain the preference values for the 4Ps, conducting four rounds of discussion (one $\mathrm{P}$ per table: Product, Price, Place and Promotion) and voting in a plenary session to determine the three most important items for each marketing strategy. At the end of the WC sessions, the information collected was used to design an AHP survey, which was emailed to the WC participants with a briefing on how to fill out the questionnaire, to be returned within the next $48 \mathrm{~h}$ after reception.

\section{The relative importance of four marketing strategies: the AHP}

The AHP was carried out to measure the relative importance of the main elements of the marketing mix strategies involved in the product, price, place and promotion policies extracted from the WC discussion sessions. The AHP methodology has been used previously to evaluate marketing mix elements (Abedi and Abedini, 2017), but to the best of our knowledge, very few studies on this have been directed at the food sector (Borrisser-Pairó et al., 2016). Prioritizing marketing mix elements can help members of the supply chain make strategic decisions to attract customers and meet their needs. The AHP is a multicriteria decision-supporting method in discrete environments, which aims to breakdown a complex decision problem into a hierarchy of smaller constituent sub-problems (Saaty, 1977, 1980). Determining the most preferred policy from a set of policies to help the untapped breeds to thrive is a decision problem for which the top level of the hierarchy represents the marketing mix strategy. It is broken down into a predefined number of characteristics (policy decisions) on the second level and their policy types on the third level (Fig. 2).

The AHP estimates elicit weights (w) for each policy and policy level to explain individual behavior in choosing the preferred marketing mix strategy. The relative importance of weight (w) for each policy $\left(\mathrm{P}_{n}\right)$ and policy type $\left(\mathrm{L}_{n . p}\right)$ [where $n(1 \ldots \mathrm{N})$ is the number of policies and $p(1 \ldots \mathrm{P})$ is the number of policy levels] is obtained from pairwise comparisons. To implement the AHP, participants in the WC discussion were asked to make two types of pairwise comparisons: (a) pairwise comparisons of the policy level; and (b) pairwise comparisons between the policies (product, price, place and promotion). The respondent first had to indicate the relative importance of the two elements compared. A nine-point scale was then used to measure the strength of this relative importance using verbal judgments (Saaty, 1980).

An example of the pairwise comparison can be seen in Table 1. Using the result elicited from this, the AHP estimated the weights (w) for each policy and policy level to explain individual behavior in choosing the preferred marketing mix strategy.

\section{Results and discussion}

Main results and discussion of the SWOT analysis of local swine systems

The most relevant SWOT for Majorcan Black Pig (MBP), Cinta Senese (CS), Noir de Bigorre (NB), Krškopolje Pig (KRS) and Turopolje pig (TP) are detailed below in Table 2. It provides a summary of the stakeholders' opinions gathered from the SWOT analysis of each local swine breed system in which differences and common aspects can be appreciated.

The strengths of these swine breeds are based on their being differentiated native breeds adapted to the land and different agro-climatic conditions, reared within traditional extensive systems, and fed using natural resources (e.g., pasture grass, cereals, legume seeds, figs, almond, acorns and several Mediterranean shrubs). Another strength is that the meat and its products have the PGI or PDO seal. Furthermore, cultural heritage and terroir products were highlighted by the stakeholders of the $\mathrm{NB}$ and KRS local systems.

One of the main strengths identified in the SWOT analysis was the high quality of the products and their link to the «heritage patrimony». This is a very important aspect of these local production systems underlined by Pensado-Leglise and Sanz Cañada (2018). However, their research also shows that these characteristics are insufficient to generate the incomes needed by farmers, which will put the sustainability of these chains at risk in the near future. In relation to this, Čandek-Potokar et al. (2018) recommended that the majority of local swine breed producers still need to be supported by subsidies to ensure their conservation. However, these authors also reinforce the idea that the best strategy is to breed systems aiming to reach self-sustainability. This may be possible through an effective marketing strategy of the meat products obtained from local swine breeds (Čandek-Potokar et al., 2018).

The weaknesses included the high costs of farming derived from a low prolificacy (reproduction rate), the consequent high price of the products and the small size of the farms. Aging farmers, product heterogeneity in terms of quality, and a lack of professionalism, collaboration and marketing strategies are challenging for these breeds to adapt to the current market demands. These weaknesses should be overcome to face current consumer demand. Moreover, these local swine breed production systems should be in line with the Local Agro-Food System (SYAL), because this would imply a better mutual cooperation network among stakeholders along the entire chain and new perspectives for public policies and for territorial and regional development projects (Muchnik et al., 2020). 
Table 1. Example of the AHP pairwise comparison across policies

\begin{tabular}{|c|c|c|c|c|c|c|c|c|c|c|c|c|c|c|c|c|}
\hline \multicolumn{9}{|c|}{ Policy 1} & \multicolumn{8}{|c|}{ Policy $n$} \\
\hline 9 & 8 & 7 & 6 & 5 & 4 & 3 & 2 & 1 & 2 & 3 & 4 & 5 & 6 & 7 & 8 & 9 \\
\hline 9 & 8 & 7 & 6 & 5 & 4 & 3 & 2 & 1 & 2 & 3 & 4 & 5 & 6 & 7 & 8 & 9 \\
\hline
\end{tabular}

Compare the following policies in a pairwise way to identify the most important one as the best marketing strategies for the added-value meat products from the untapped swine breeds.

Table 2. Summary of stakeholders' points of view from SWOT analysis of each local swine breed system: differences and common aspects

\begin{tabular}{|c|c|c|c|c|c|}
\hline Breed & $\mathrm{N}^{\circ}$ & Strengths & Weaknesses & Opportunities & Threats \\
\hline \multirow[t]{3}{*}{ MBP } & 1 & $\begin{array}{l}\text { Differentiated native breed } \\
\text { adapted to the territory and } \\
\text { agro-climatic conditions }\end{array}$ & Elevated farming costs & $\begin{array}{l}\text { Expansion to international } \\
\text { market }\end{array}$ & $\begin{array}{l}\text { Competition with Iberian pig } \\
\text { products }\end{array}$ \\
\hline & 2 & PGI of the sobrassada & $\begin{array}{l}\text { Small size of the farms and } \\
\text { the heterogeneity of the } \\
\text { products' quality }\end{array}$ & $\begin{array}{l}\text { Building customer loyalty } \\
\text { within the local Majorcan } \\
\text { market }\end{array}$ & $\begin{array}{l}\text { Low price of meat products } \\
\text { from other commercial swine }\end{array}$ \\
\hline & 3 & $\begin{array}{l}\text { High intrinsic sensory quality of } \\
\text { meat and meat products }\end{array}$ & Lack of professionalism & $\begin{array}{l}\text { Promotion of PGI meat } \\
\text { products }\end{array}$ & Fat content \\
\hline \multirow[t]{3}{*}{ CS } & 1 & $\begin{array}{l}\text { Traditional rearing system and the } \\
\text { know-how of farmers ensure meat } \\
\text { and meat products with excellent } \\
\text { sensory features }\end{array}$ & $\begin{array}{l}\text { CS fresh meat is scarcely } \\
\text { available outside Tuscany }\end{array}$ & $\begin{array}{l}\text { Working on a better } \\
\text { communication strategy } \\
\text { for the breed and its } \\
\text { products }\end{array}$ & $\begin{array}{l}\text { Products' frauds increasing } \\
\text { distrust of consumers and } \\
\text { their concerns for health and } \\
\text { animal welfare }\end{array}$ \\
\hline & 2 & $\begin{array}{l}\text { Meat has earned the PDO to give } \\
\text { a strong identity to CS }\end{array}$ & $\begin{array}{l}\text { CS system is fragmented } \\
\text { between farms and } \\
\text { processing industries }\end{array}$ & $\begin{array}{l}\text { Collaboration with } \\
\text { renowned chefs to enlarge } \\
\text { the consumer knowledge }\end{array}$ & $\begin{array}{l}\text { CS systems are dealing with } \\
\text { consumers' increasing } \\
\text { disinformation about food } \\
\text { and agriculture systems }\end{array}$ \\
\hline & 3 & $\begin{array}{l}\text { Creating a rewarding niche } \\
\text { market for environmentally } \\
\text { sensitive consumers }\end{array}$ & $\begin{array}{l}\text { Lack of communication } \\
\text { and collaboration and lack } \\
\text { of shared marketing } \\
\text { strategies }\end{array}$ & The PDO label & $\begin{array}{l}\text { Elder farmers who keep } \\
\text { adopting inefficient } \\
\text { management and market } \\
\text { strategies }\end{array}$ \\
\hline \multirow[t]{3}{*}{ NB } & 1 & $\begin{array}{l}\text { High sensorial quality (flavor) of } \\
\text { the products }\end{array}$ & $\begin{array}{l}\text { Managing variability at } \\
\text { each stage of production }\end{array}$ & $\begin{array}{l}\text { Heritage of the chain as a } \\
\text { factor of attractiveness for } \\
\text { tourism and institutions }\end{array}$ & $\begin{array}{l}\text { Sanitary crises (epizootic } \\
\text { epidemic, African swine fever) } \\
\text { at national, European or } \\
\text { international levels }\end{array}$ \\
\hline & 2 & $\begin{array}{l}\text { PDO label (breed, know-how and } \\
\text { terroir) as protector of NB chain }\end{array}$ & $\begin{array}{l}\text { Variability between farms } \\
\text { in the sanitary risk }\end{array}$ & $\begin{array}{l}\text { Use of local resources } \\
\text { developed by the } \\
\text { NB chain meet the social } \\
\text { expectations of } \\
\text { consumers }\end{array}$ & $\begin{array}{l}\text { Confusion with the adjective } \\
\text { 'black' used by other swine } \\
\text { chains }\end{array}$ \\
\hline & 3 & $\begin{array}{l}\text { Feeding natural resources, } \\
\text { outdoor production system }\end{array}$ & $\begin{array}{l}\text { No control of use breed } \\
\text { outside the PDO area }\end{array}$ & $\begin{array}{l}\text { Intrinsic quality (sensory, } \\
\text { nutritional...) }\end{array}$ & Declining meat consumption \\
\hline \multirow[t]{3}{*}{ KRS } & 1 & $\begin{array}{l}\text { Non-intensive traditional way of } \\
\text { rearing }\end{array}$ & $\begin{array}{l}\text { The value of breed is not } \\
\text { sufficiently distinguished }\end{array}$ & $\begin{array}{l}\text { Need for branding } \\
\text { strategy 'back to nature' }\end{array}$ & $\begin{array}{l}\text { The inability of breeders to } \\
\text { achieve the expected price } \\
\text { levels }\end{array}$ \\
\hline & 2 & $\begin{array}{l}\text { High meat quality (sensory } \\
\text { properties) }\end{array}$ & $\begin{array}{l}\text { The quality of meat } \\
\text { products is not adequately } \\
\text { standardized }\end{array}$ & $\begin{array}{l}\text { Differentiate sales } \\
\text { channels through tourism, } \\
\text { HoReCa sector, gifts }\end{array}$ & $\begin{array}{l}\text { Intensification of the rearing } \\
\text { mode, lack of the quality } \\
\text { rules }\end{array}$ \\
\hline & 3 & $\begin{array}{l}\text { Cultural heritage related to the } \\
\text { KRS systems }\end{array}$ & $\begin{array}{l}\text { Lack of standardized } \\
\text { production process }\end{array}$ & $\begin{array}{l}\text { Consumers' perceptions } \\
\text { of local products and } \\
\text { extensive production } \\
\text { systems }\end{array}$ & $\begin{array}{l}\text { Missing intermediate factors } \\
\text { in the value chain }\end{array}$ \\
\hline \multirow[t]{3}{*}{ TP } & 1 & $\begin{array}{l}\text { The long-standing tradition in its } \\
\text { breeding }\end{array}$ & $\begin{array}{l}\text { Long and expensive } \\
\text { production cycle }\end{array}$ & $\begin{array}{l}\text { Increasing purchasing } \\
\text { power of some consumer } \\
\text { segments }\end{array}$ & $\begin{array}{l}\text { Higher exposure to animal } \\
\text { diseases and } \\
\text { unfavorable weather } \\
\text { conditions }\end{array}$ \\
\hline & 2 & $\begin{array}{l}\text { Swine are raised outdoor and fed } \\
\text { with naturally available feedstuffs }\end{array}$ & $\begin{array}{l}\text { Low prolificacy (small } \\
\text { number of piglets) }\end{array}$ & Use of celebrity marketing & $\begin{array}{l}\text { Competition with other local } \\
\text { swine breeds }\end{array}$ \\
\hline & 3 & Meat products with PGI & $\begin{array}{l}\text { High mortality rate and } \\
\text { consequently the high } \\
\text { price of TP products }\end{array}$ & $\begin{array}{l}\text { Support of local } \\
\text { authorities in application } \\
\text { for PGI }\end{array}$ & $\begin{array}{l}\text { Low interest and } \\
\text { unfamiliarity of wider range } \\
\text { of consumers with products } \\
\text { of TP }\end{array}$ \\
\hline
\end{tabular}




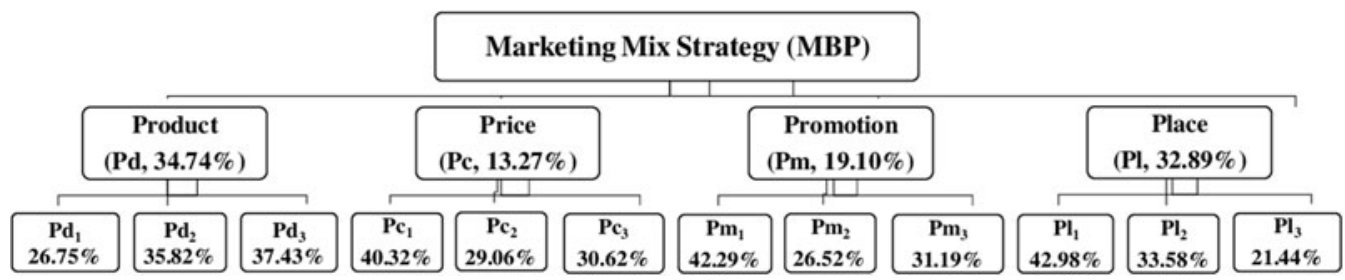

Fig. 3. Hierarchical structure used to value the best policy for the MBP breed. Product (Pd): $\mathbf{P d _ { 1 }}$ : Boost $\mathbf{P G I}$ brand, $\mathbf{P} \mathbf{d}_{\mathbf{2}}$ : Enhance the organoleptic quality of the product, $\mathbf{P d}_{\mathbf{3}}$ : Diversify the product and adapt to the needs of the young consumer. $\mathbf{P l a c e}(\mathbf{P l})$ : $\mathbf{P} \mathbf{l}_{\mathbf{1}}$ : Selling $\mathbf{M B P}$ products in local restaurants, $\mathbf{P} \mathbf{l}_{\mathbf{2}}$ : Distribution of sobrassada in local shops, $\mathbf{P l}_{\mathbf{3}}$ : (MBP sector) with access to different distribution channels. Promotion (Pm): $\mathbf{P m} \mathbf{m}_{\mathbf{1}}$ : Marketing strategies based on public relations (food and gastronomic events), $\mathbf{P m}_{\mathbf{2}}$ : Promotion in primary schools with the support of the Public Administration, $\mathbf{P m} \mathbf{m}_{\mathbf{3}}$ : TV promotion, and $\mathbf{P r i c e}$ (Pc): $\mathbf{P} \mathbf{c}_{\mathbf{1}}$ : To maintain a high price strategy based on a premium category, $\mathbf{P C}_{\mathbf{2}}$ : To increase the transparency of prices along the production chain, and $\mathbf{P c}_{\mathbf{3}}$ : To apply a premium strategy along all the production chain.

The opportunities were based on strengthening consumer loyalty within the local market, including the tourist market, and the promotion of traditional products with a PGI or a PDO label, highlighting their international expansion. Growing market demand for different cuts of fresh meat in the retail market and for high-quality fresh meat and ready-to-eat formats in the HORECA sector (HOtels, REstaurants and CAtering) has made the strategy of launching innovative products an attractive business opportunity, with positive consumer perceptions of local products and production systems.

All the main threats center on competition with other local swine breeds, mainly in the MBP and NB chain, and with other low-priced commercial meat products made from quality cuts. Also mentioned were the misconceptions surrounding the word black among the NB and Iberian products. Furthermore, consumers' negative perceptions regarding the high fat content of meat products and product frauds increase mistrust among consumers, and their health and animal welfare concerns may determine the swine breeds' survival. Another concern was regarding the aging farmers who adopt inefficient management practices.

To sum up, one of the main strengths identified from the SWOT analysis was the high quality of the products and their link to cultural patrimony. This is a very important aspect of these local production systems, underlined by Pensado-Leglise and Sanz Cañada (2018). However, these authors also explain that the identified strengths are insufficient to justify the continued payments to farmers, risking the sustainability of these chains in the near future. They also point out that there may not be sufficient market support for these local systems, biodiversity and cultural patrimony. Along these lines, Čandek-Potokar et al. (2018) recommend that most local swine breed production still need to be supported by subsidies to ensure their conservation. However, these authors also reinforce the idea that the best approach is making these breed systems self-sustainable, which may be possible with an efficient marketing strategy for their products. Another approach is the work of Sanz-Cañada and Muchnik (2016), who emphasized that these Local Agro-Food System (SYAL), built on identity-based food products, could be crucial for a more sustainable rural development. But, of utmost importance is the cooperation between farms, firms and institutions.

Main marketing strategies of the local systems based on the $4 P$ analysis: implications for the potential to introduce the products into the market and for conserving the swine breeds

No scientific or systematized studies have previously been undertaken or published on marketing strategies for the self-sustainability of the five autochthonous swine breeds. There may only be a few publications containing descriptive characteristics.

\section{Majorcan Black Pig}

The most relevant product policy identified by stakeholders was the diversification of meat products to increase the position of the MBP brand in the market (37.43\%) by including innovations focused on the nutritional properties of the products, process innovation and format size, thereby meeting consumer demands (Vitale et al., 2020), and strengthening the PGI brand (26.75\%) (Fig. 3). Also relevant was improving the sensory quality of the products $(35.82 \%)$, including extending their shelf life and highlighting their nutritional value. These strategies are similar to the ones mentioned by Guerrero (2001).

Regarding the place strategy, increasing the presence of MBP processed food, including sobrassada (seasoned, dried and fermented sausage with a PGI certification), porcella (suckling piglet) and fresh meat cuts, in local restaurants, was identified as one of the most important strategies (42.98\%), together with enhancing the availability of sobrassada in local shops (33.58\%). Besides, stakeholders stated that the PGI Regulatory Council and public administrations must be encouraged to support commercial actions that ensure the presence of MBP processed food in large retailers, thereby strengthening the MBP image (21.44\%). These findings support the conclusions from Giraud (2002), who suggested that marketing plans of typical foods should mainly focus on local consumers.

The most relevant action (42.29\%) for the promotion strategy was to increase the presence of MBP products at sectoral and gastronomic fairs via public relations, followed by promotion on $\mathrm{TV}$, online and in the press $(31.19 \%)$, and the promotion of MBP products in primary schools with public administration support $(26.52 \%)$. Furthermore, the proposed branding strategy using the TREASURE projects as support was considered as a 'marketing tool that could promote the MBP as a differentiated and autochthonous swine production system'.

The stakeholders' price strategy (40.32\%) was to maintain a high price based on a premium category. Some stakeholders also advocated for a different distribution of prices along the production chain, which would favor higher revenues for farmers, indirectly promoting the development of the primary sector. This aligns with some policy initiatives such as those launched by the French and Spanish governments to develop value chain legislation aimed at ensuring a minimum price for farmers.

\section{Cinta Senese}

In this system, product heterogeneity is considered a hurdle for building a loyal customer base. Thus, the most relevant product strategies were to improve the standardization of the food processing among producers (38.15\%) (Fig. 4) and to promote the healthier nutritional properties of the processed food (35.75\%). 


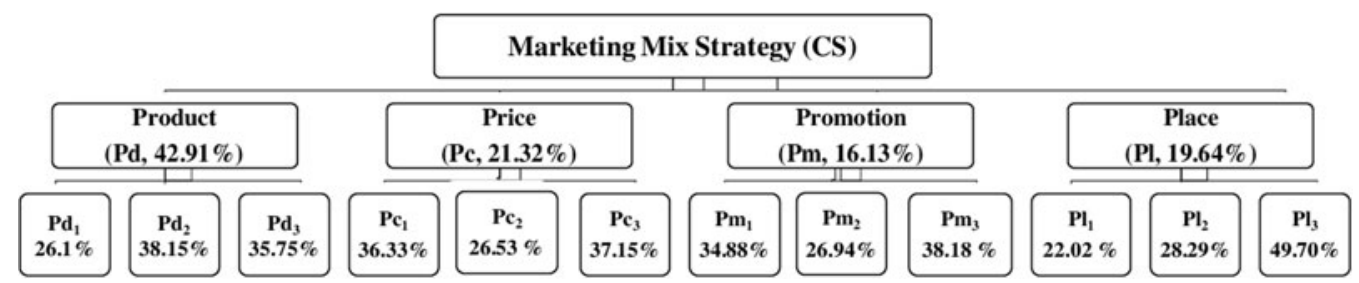

Fig. 4. Hierarchical structure used to value the best policy for the CS breed. Product ( $\mathbf{P d}$ ): $\mathbf{P d}_{\mathbf{1}}$ : Increase the diffusion of fresh meat, $\mathbf{P} \mathbf{d}_{\mathbf{2}}$ : Healthier products (less salt, less additives), $\mathbf{P d}_{\mathbf{3}}$ : Improve the standardization of manufacturing process among producers to ensure homogeneous products. $\mathbf{P l a c e}\left(\mathbf{P I )}\right.$ : $\mathbf{P} \mathbf{l}_{\mathbf{1}}$ : Stores of topquality products (also GDO with gourmet lines), $\mathbf{P l}_{\mathbf{2}}$ : Local shops, $\mathbf{P l}_{\mathbf{3}}$ : High quality restaurants. Promotion ( $\mathbf{P m}_{\mathbf{m}}$ : $\mathbf{P m}_{\mathbf{1}}$ : Collaboration with chefs, $\mathbf{P m}_{\mathbf{2}}$ : Collaboration with cooking schools, $\mathbf{P m}_{\mathbf{3}}$ : Promotion on social networks. Price (Pc): $\mathbf{P c}_{\mathbf{1}}$ : Different price between organic and conventional products, $\mathbf{P} \mathbf{c}_{\mathbf{2}}$ : Different prices depending on feeding strategy (i.e. finishing with acorn/chestnut or concentrate), and $\mathbf{P c}_{\mathbf{3}}$ : Higher price, but let the consumers try the products in stores.

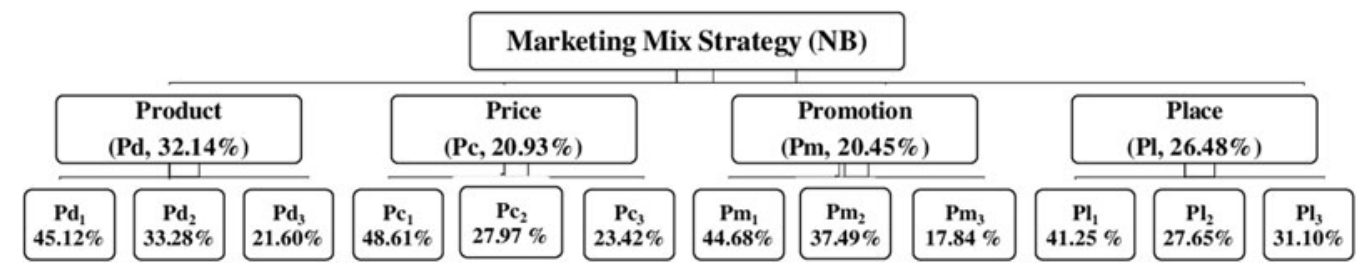

Fig. 5. Hierarchical structure used to value the best policy for the Noir de Bigorre chain-Gascon breed. Product (Pd): $\mathbf{P} \mathbf{d}_{\mathbf{1}}$ : To obtain traceability/identification card for ham and loin, $\mathbf{P d}_{\mathbf{2}}$ : To set up ageing room in the open-air, $\mathbf{P d}_{\mathbf{3}}$ : To bring to market knife sliced products. $\mathbf{P l a c e}(\mathbf{P l})$ : $\mathbf{P} \mathbf{l}_{\mathbf{1}}$ : To extend the coverage of local stores in DPO area, $\mathbf{P l}_{\mathbf{2}}$ : To develop their export sales. $\mathbf{P l}_{\mathbf{3}}$ : To work with specialized high-end network. Promotion (Pm): $\mathbf{P} \mathbf{m}_{\mathbf{1}}$ : To support products from processing to tasting (showcase of products, cooking lesson), $\mathbf{P m}_{\mathbf{2}}$ : To provide training in products history for all actors participating in product's sale, Pm $\mathbf{m}_{\mathbf{3}}$ To build two promotions:

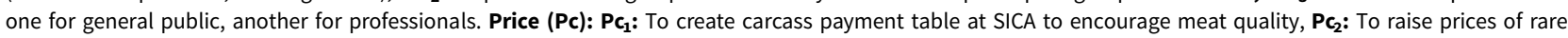
products (dry-cured ham, dry sausage), and $\mathbf{P c}_{3}$ : To raise pig price at SICA.

Modifying some of these characteristics, including reducing the salt and additive content, would help to better match customer needs. Increasing sales of raw meat should also eventually be promoted (26.10\%); indeed, this type of product can be sold directly by the farmer, representing an immediate source of income and an interesting tool for rural development (Chambers et al., 2007; Sanjuán et al., 2012). Moreover, producers believe that the sensory traits associated with CS are more appreciated in fresh meat than in processed food. There was a certain disagreement among stakeholders regarding the prioritization of place strategies, with two strategies of almost equal importance emerging. The two most relevant strategies for the sale and distribution of CS processed food were high-quality restaurants $(37.15 \%)$ followed by stores selling top-quality products (36.33\%). The latter category also includes GDO (large-scale distribution) gourmet lines, even though most of the producers were against GDO sales policies. Despite the increasing difficulties faced by local stores such as butchers' shops to compete with GDO, they remain an important selling channel, making this placing strategy still worthwhile (26.53\%). Moreover, short supply chains and local retailers are preferred over GDO for high added-value products such as PDO and/or PGI-labeled products, since they can provide consumers with direct information about meat origin, processing methods and animal rearing systems (Marsden et al., 2000; Ilbery et al., 2004).

Within this context, the promotion policy using social networks was considered the most important one for the CS system (38.18\%), followed by collaboration with renowned chefs (34.88\%) and cooking schools (26.94\%), which might help raise the profile of CS products outside Tuscany. Limited consumer knowledge of the breed and GDO competition for price polices were considered to be strong hurdles for price strategies in the CS chain. However, stakeholders firmly agreed that a further price increase could be an attractive strategy (49.70\%) to differentiate CS production systems and acknowledge their value, but that it should go hand in hand with an enhanced marketing strategy, possibly encouraging tasting experiences at purchasing points.

\section{Noir de Bigorre}

The product strategy is a priority for the Noir de Bigorre chain-Gascon breed and is related to the development of products and their image. To strengthen product traceability for consumers, it was considered that an 'identity card' for hams and loins would enable a certain product to be associated with a particular farmer and the pig feeding method or practices (45.12\%) (Fig. 5). The implementation of open-air drying/ripening rooms (33.28\%) and the (increased) possibility of marketing ham slices cut with a knife (rather than a slicer) are possible innovations in the chain $(21.60 \%)$.

The place strategy is ensured by the coverage of local stores in the PDO area, serving as ambassadors for the products (41.25\%) and improving local product visibility. Working with a high-end specialized network $(31.10 \%)$, possibly outside the geographical area of production, would be another opportunity to promote the distribution and sale of NB processed food.

Regarding the promotion strategy, this is mainly linked to its heritage dimension. This result is in line with the work of Sanz-Cañada and Muchnik (2016), who showed that identitybased food is related to territory. To support these products, it is important to focus on their showcasing and cooking lessons highlighting their sensory characteristics (44.68\%). Different promotional strategies have been identified based on the relationship between the food and its story. Training in the product history for all the stakeholders in the sale of the product is a key element (37.49\%). A two-pronged product promotion strategy was considered, one for the public, based around the PDO and the 


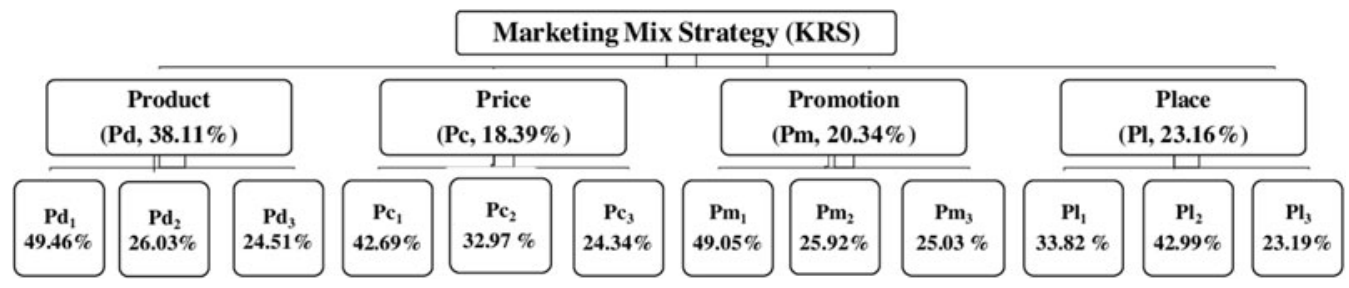

Fig. 6. Hierarchical structure used to value the best policy for the KRS breed. Product (Pd): $\mathbf{P d}_{1}$ : Dry-cured products, $\mathbf{P d}_{2}$ : Fresh Meat, $_{\mathbf{P d}}$ : Innovative culinary products. Place (Pl): $\mathbf{P l}_{1}$ : Good, high-cuisine restaurants, $\mathbf{P} \mathbf{P}_{\mathbf{2}}$ : Direct sales (on farms, and to companies for business gifts), $\mathbf{P} \mathbf{l}_{3}$ : $\mathbf{P}$ State protocol. Promotion $(\mathbf{P m})$ : $\mathbf{P} \mathbf{m}_{\mathbf{1}}$ : Prestigious brand, $\mathbf{P m}_{\mathbf{2}}$ : Guided tours, tasting, $\mathbf{P m}_{\mathbf{3}}$ : Through educational institutions. Price $\left(\mathbf{P c}_{\mathbf{c}}\right)$ : $\mathbf{P \mathbf { c } _ { \mathbf { 1 } }}$ : Premium price, $\mathbf{P c}_{\mathbf{2}}$ : Differentiated price and $\mathbf{P c}_{3}$ : Price adjusted to sales channel.

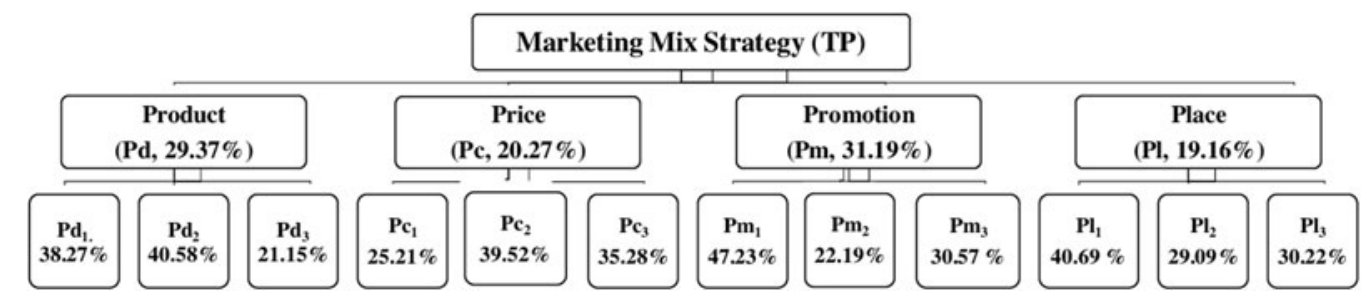

Fig. 7. Hierarchical structure used to value the best policy for the TP breed. Product (Pd): $\mathbf{P d}_{\mathbf{1}}$ : To obtain "Protected Designation of Origin" (PDO) status, $\mathbf{P} \mathbf{d}_{\mathbf{2}}$ : Standardization of production (recipe), $\mathbf{P d}_{\mathbf{3}}$ : Exclusive packaging. $\mathbf{P l a c e}(\mathbf{P l})$ : $\mathbf{P l}_{\mathbf{1}}$ : In specialized shops, $\mathbf{P l}_{\mathbf{2}}$ : Direct sale $\mathbf{P l}_{\mathbf{3}}$ : In restaurants. $\left.\mathbf{P r o m o t i o n} \mathbf{(} \mathbf{P m}\right)$ : $\mathbf{P m}_{\mathbf{1}}$ : Promotion of healthy, ecological, indigenous, traditional, high-quality products, $\mathbf{P m}_{\mathbf{2}}$ : Direct marketing (fairs, local events, oral submission ...), Pm: Use Turopolje heritage in promotion. Price $(\mathbf{P c})$ : $\mathbf{P} \mathbf{c}_{\mathbf{1}}$ : Premium price for premium products, $\mathbf{P} \mathbf{c}_{\mathbf{2}}$ : All Turopolje pig products should be in the same premium price segment and $\mathbf{P C}_{3}$ : Aligned price strategy along the entire value chain.

acknowledgement of values of the NB chain, and the other for professionals (17.84\%).

Last, the price strategy is based on a modification of the carcass payment grid to include meat quality indicators $(48.61 \%)$ in an attempt to improve the quality of the meat and fat and to manage its variability.

\section{Krškopolje Pig}

The stakeholders described dry-cured products, fresh meat and innovative culinary products to be the three most important product strategies. Following the AHP analysis, the highest relative importance (Fig. 6) was assigned to dry-cured products $(49.46 \%)$.

Regarding the place strategy, the AHP analysis revealed that stakeholders considered the most important channel for the products from the breed (42.99\%) to be direct sales, with business gifts mentioned. This type of distribution is further supported by the significant importance given to state protocol (use as gifts and in gala dinners) $(23.29 \%)$ as the third most important distribution channel. Good high-cuisine restaurants were recognized as the second most important distribution channel (33.82\%).

Focusing on the promotion strategy, having a prestigious seal was recognized by stakeholders as the most important (49.05\%), and given twice as much weight as the next two key promotion strategies identified, namely guided tours with tasting (25.92\%) and promotion via educational institutions $(25.03 \%)$. The importance of the use of these products as state protocol gifts and the promotion of the breed and its products in education centers and schools were highlighted. Last, the key price policy strategies established with the AHP methodology were premium price, differentiated price and price adjusted to the sales channel. The premium price strategy was given the greatest weight (42.69\%). In summary, the recognized assets were mainly non-intensive traditional rearing, good quality and flavor, and cultural heritage, while the main shortcomings were a disorganized value chain and no processed food standardization. The localized agro-food systems concept (SYAL) could be an interesting tool to improve cooperation in this chain (Muchnik et al., 2008).

\section{Turopolje Pig}

The product strategy for TP processed food should rely on high product quality and be used for product positioning. This is in line with previous research (Cerjak et al., 2014) showing that Croatian consumers perceive a better quality of traditional products as one of the major motives for their purchase.

One of the most important elements of product policy is the standardization of processed food (40.58\%) (Fig. 7). Next to it is the use of quality labels, with priority given to the PDO quality sign (38.27\%) and the organic label, customer perception associated with higher product positioning, purchase frequency and willingness to pay, as shown by Bryła (2017). Due to market saturation in terms of exclusive products, TP processed food should be sold in smaller packages and using innovative strategies such as sales in gift baskets. Images of the Turopolje region and/or TP should be used on the packages $(21.15 \%)$ to highlight the product origin.

Regarding the place strategy, TP products could only be purchased directly from producers and were occasionally served in local restaurants, which was recognized as a major problem. Therefore, while representing an important percentage (29.09\%), direct sales were evaluated as less important than sales in specialized shops (40.69\%) and restaurants (30.22\%). These findings are in line with a previous study (Jensen et al., 2019) which showed that Danish local food consumers support short food chains. Only a few respondents agreed with an online sales strategy.

Focusing on the promotion policy, most of the stakeholders stated that the main message they would convey to consumers 
(a)



Majorcan Black Pig (MBP)

(c)

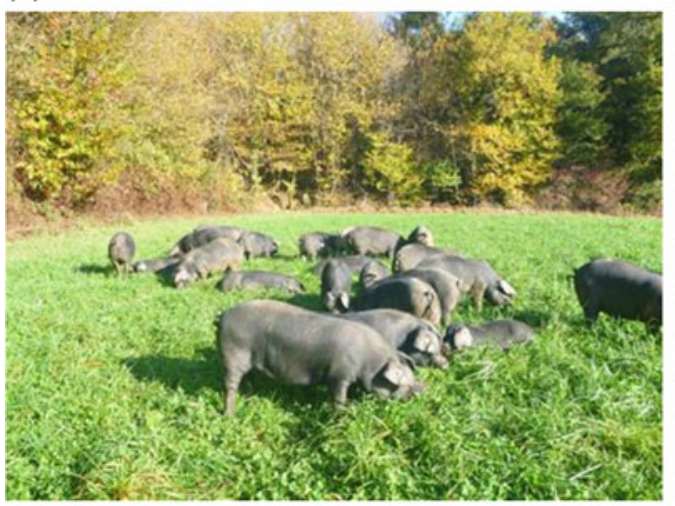

Gascon pig - Noir de Bigorre chain (NB) (b)

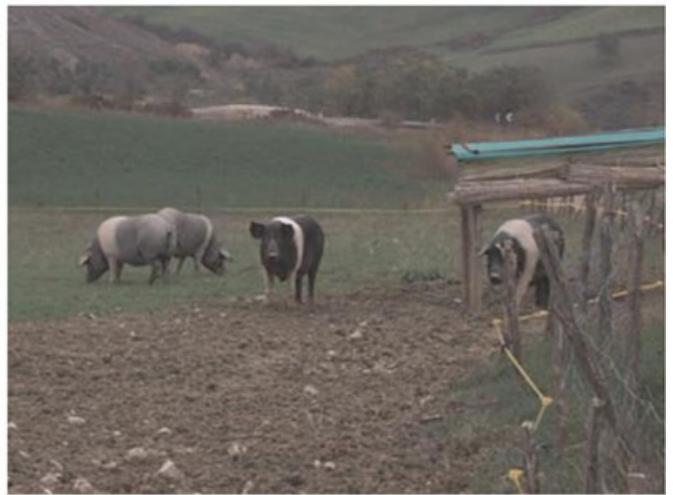

Cinta Senese (CS)

(d)

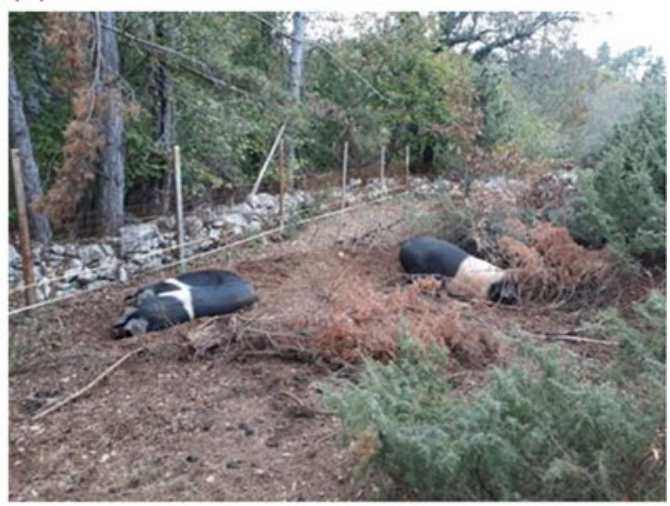

Krškopoljski prašič (KRS)

(e)

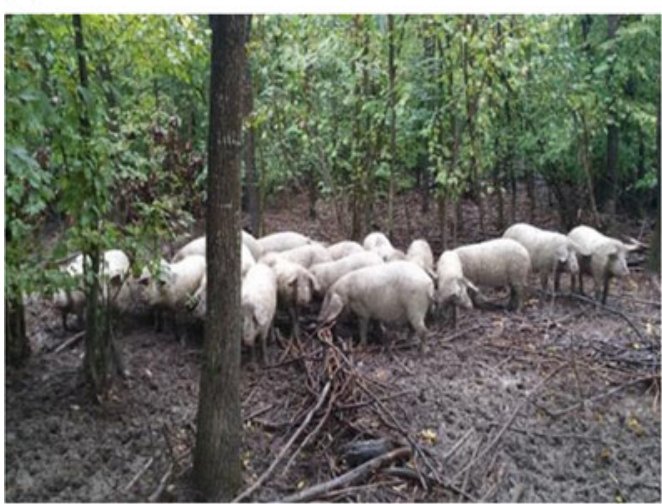

Turopolje pig (TP)

Fig. 8. Growing finishing pig from Mallorca island (a), Tuscany (b), Hautes-Pyrénées (c), Slovenia (d) and Turopolje region (e).

is that TP processed foods are healthy, environmentally friendly and of high quality, representing the tradition and indigenous nature of the breed and the raw materials involved (47.23\%). However, a few respondents stated that they would segment consumers and use messages adapted to each type of target. Storytelling, which involved sharing stories about the history and traditions of the Turopolje region (30.57\%), was considered an important promotion strategy. Respondents agreed on the usefulness of direct marketing, including promotion at fairs and local events, word of mouth and others (22.19\%). Promotion through social networks (Facebook, Instagram, Twitter, etc.) was likewise considered a prospective promotional strategy. Last, all stakeholders agreed that TP products should cost a premium price due to their expensive production and product exclusivity. However, some stakeholders held a different opinion on the pricing strategy within the supply chain, believing that adding value to a product (e.g., exclusive packaging) should also influence the selling price (25.21\%). Some respondents emphasized 
the need for common price negotiation if processed foods were to be standardized.

\section{Strategies of the local systems}

The extensive or semi-extensive local grazing systems characterizing the five swine breeds addressed in this study (Fig. 8) are essential toward the conservation and enhancement of high natural value farming systems, as described by Varga et al. (2016). Autochthonous breeds play a role in supporting agroecosystem resilience (Hajjar et al., 2008), maintaining socio-cultural traditions, local identities, traditional knowledge (Nautiyal, 2018) and cultural landscapes (Tisdell et al., 2003), all of which are public goods and attributes identified in our study.

Recent research has demonstrated that the best chance of conserving the genetic diversity of autochthonous swine breeds comes from a mix of looking for niche markets for the processed food and increasing awareness among consumers who appreciate the high quality of traditional meat products (Kallas et al., 2019). To this effect, the stakeholders in the present study identified the following actions as the best product strategies: enhancing and highlighting the sensory quality of the meat products, boosting the geographical indications and traditional specialties of the breed, where appropriate (PGI and PDO), improving the standardization of the food processing among producers to ensure homogeneous products, and increasing product diversity and traceability. This is in line with the emergent interest in local foods, where consumers perceive to have higher quality standards and to be tools for preserving tradition and local know-how (Gilg and Battershill, 1998; Weatherell et al., 2003; Vecchio, 2011). In addition, the PDO and PGI logos are commonly considered the main purchasing motivation for a shopper with excellent knowledge of the EU certification label, according to Vecchio and Annunziata (2011). However, a better understanding of the relationships between people, products, and territory will be crucial to the survival of these local systems. Our study hints at organizational differences among these systems. Hence, in some of the studied chains (Cinta Senese and Krškopolje Pig), better cooperation among the stakeholders and major collective action is needed. This cooperation would improve the governance and increase negotiation ability with the other stakeholders related to the marketing strategy, as described by Pensado-Leglise and Sanz Cañada (2018).

Regarding the price strategy, maintaining a high price based on a premium category while letting consumers taste the product in situ (show-cooking, direct marketing) and establishing price differentiation depending on feeding (extensive $v s$ concentrate) were identified as key elements in our study, which is also in agreement with Stampa et al. (2020).

With regards to the place strategy, the stakeholders identified the need to increase the presence of traditional products in the HORECA sector and to improve and intensify their presence in specialized local food shops selling top-quality products and gourmet foods. This strategy, which was identified in most of the chains studied, is in line with Jensen et al. (2019). Similarly, Conner and Oppenheim (2008) showed that natural food stores were the most promising distribution channel.

Several common strategies identified to promote the processed food from local systems were based on public relations, including food and gastronomic events, tourist events, workshops, guided tours, direct sales to companies for business gifts, web pages and collaboration with catering schools, popular chefs and athletes. They highlighted that any promotional message should include information about the history of the product and its healthy properties. However, the concept of 'growing in', referring to the information about the product origin, as discussed in the study from the USA by Conner et al. (2009), must be enhanced. This aspect was not given enough consideration by the stakeholders of these European local systems. Securing public administration support is recommended to develop these aspects.

\section{Concluding remarks}

The participative bottom-up mixed-methods approach used in this study involving the key stakeholders in each untapped breed value chain is novel and enabled us to co-construct the identified strategies. This methodology increases the likelihood of successfully implementing these strategies since they are not seen as impositions from external agents.

The main parameters of this study of untapped swine breeds were based on non-intensive traditional rearing, good sensory quality and cultural heritage. The extensive production systems that characterize these native breeds are fully aligned with sustainability since they are an essential element in the conservation and enhancement of high nature value local farming systems.

The stakeholders identified having PGI and PDO seals as being of utmost importance to enhance the sensory quality of the products, improve the standardization and traceability of the food processing to ensure homogeneous products, and to enhance their high price based on the premium category and direct sales. Iberian meat products could be a strong competition mainly to the MBP and NB breeds and hence effective product identification and traceability is highly important. The stakeholders of these autochthonous breeds must place greater emphasis on highlighting grazing as a feeding strategy (extensive or semi-extensive), the meat products derived from the swine and their origin.

Acknowledgements. This study has received funding from the European Union's Horizon 2020 Research and Innovation program under grant agreement No 634476 (project acronym TREASURE). IRTA thanks CERTA funding. Authors thank Jaume Jaume (Semilla-Caib), who supported the organization of the study in Mallorca Island; Florence Garcia-Launay and Ludovic Brossard (PEGASE, INRAE, 35590 Saint-Gilles, France) and Alexandre Fonseca (Consortium Noir de Bigorre) who participated in the organization of the French case study and realization of the focus-groups. E. A. Rivera-Toapanta is a recipient of a doctoral fellowship awarded by the INIA (Instituto Nacional de Investigación y Tecnología Agraria y Alimentaria). This work has been carried out within the framework of the Doctorate Program in Food Sciences of the Autonomous University of Barcelona. The content of this paper reflects only the authors' view and the European Union Agency is not responsible for any use that may be made of the information it contains.

Author contributions. Evelyn Rivera-Toapanta: investigation, formal analysis, writing original draft, supervision, visualization. Zein Kallas: project administration, methodology, conceptualization, investigation and writing review and editing, supervision. Meta Čandek-Potokar: conceptualization, project administration, writing-review and editing, funding acquisition. Joel Gonzalez: conceptualization, investigation and writing original draft. Marta Gil: supervision, project administration, investigation, writing-review and editing. Elsa Varela: conceptualization, investigation, writing-review and editing, methodology. Justine Faure: conceptualization, investigation and writing original draft. Marija Cerjak: investigation, writing-review and editing. Tomažin Urška: investigation, writing-review and editing. Chiara Aquilani: investigation, writing original draft and writing-review and editing. Bénédicte Lebret: conceptualization, project administration, investigation, writing-review and editing, funding acquisition. Danijel Karolyi: conceptualization, project 
administration, investigation, writing-review and editing, funding acquisition. Carolina Pugliese: conceptualization, project administration, investigation, writing-review and editing, funding acquisition. José Maria Gil: project administration, methodology, conceptualization, funding acquisition.

\section{References}

Abedi G and Abedini E (2017) Prioritizing of marketing mix elements effects on patients' tendency to the hospital using analytic hierarchy process. International Journal of Healthcare Management 10, 34-41.

Borrisser-Pairó F, Kallas Z, Panella-Riera N, Avena M, Ibáñez M, Olivares A, Gil JM and Oliver MA (2016) Towards entire male pigs in Europe: a perspective from the Spanish supply chain. Research in Veterinary Science 107, 20-29.

Bozzi R and Crovetti A (2013) Conservational issues in local breeds-state of the art. 8th International Symposium on the Mediterranean Pig Ljubljana. p. 4, 9-14.

Brown C (2003) Consumers' preferences for locally produced food: a study in southeast Missouri on JSTOR. American Journal of Alternative Agriculture 18, 213-224.

Bryła P (2017) The perception of EU quality signs for origin and organic food products among Polish consumers. Quality Assurance and Safety of Crops and Foods 9, 345-355.

Čandek-Potokar M and Nieto R (2019) European local pig breeds-diversity and performance. A study of project TREASURE.

Čandek-Potokar M, Giusto A, Conti C, Cosola C and Fontanesi L (2018) Improving sustainability of local pig breeds using quality labels-case review and trademark development in project TREASURE. Archivos de Zootecnia 1(Supp1), 235.

Cerjak M, Haas R, Brunner F and Tomić M (2014) What motivates consumers to buy traditional food products? Evidence from Croatia and Austria using word association and laddering interviews. British Food Journal 116, 1726-1747.

Chambers S, Lobb A, Butler L, Harvey K and Bruce Traill W (2007) Local, national and imported foods: a qualitative study. Appetite 49, 208-213.

Conner DS and Oppenheim D (2008) Demand for pasture-raised livestock products in Michigan: results of consumer surveys and experimental auctions. Journal of Food Distribution Research 39, 45-50.

Conner DS, Montri AD, Montri DN and Hamm MW (2009) Consumer demand for local produce at extended season farmers' markets: guiding farmer marketing strategies. Renewable Agriculture and Food Systems 24, 251-259.

Font-i-Furnols M and Guerrero L (2014) Consumer preference, behavior and perception about meat and meat products: an overview. Meat Science 98, 361-371.

Gilg AW and Battershill M (1998) Quality farm food in Europe: a possible alternative to the industrialised food market and to current agri-environmental policies: lessons from France. Food Policy 23, 25-40.

Giraud G (2002) Consumer perception of typical food products in Europe. Xth EAAE Congress Exploring Diversity in the European Agri-Food System Zaragoza.

Guerrero L (2001) Marketing PDO (products with denominations of origin) and PGI (products with geographical identities). In Frewer Lynn, Risvik Einar and Schifferstein Hendrik (eds), Food, People and Society. Berlin, Heidelberg: Springer Berlin Heidelberg, pp. 281-297. https://doi.org/ 10.1007/978-3-662-04601-2_18.

Guerrero L, Claret A, Verbeke W, Vanhonacker F, Enderli G, Sulmont-Rossé C, Hersleth M and Guàrdia MD (2012) Cross-cultural conceptualization of the words traditional and innovation in a food context by means of sorting task and hedonic evaluation. Food Quality and Preference 25, 69-78.

Hajjar R, Jarvis DI and Gemmill-Herren B (2008) The utility of crop genetic diversity in maintaining ecosystem services. Agriculture, Ecosystems \& Environment 123, 261-270.

Horizon 2020 Programme (2015) Treasure-diversity of local pig breeds and production systems for high quality traditional products and sustainable pork chains. Treasure.kis.si [Internet]. Available at website https://treasure.kis.si/.
Howard PH (2006) Central coast consumers want more food-related information, from safety to ethics. California Agriculture 60, 14-19.

Ilbery B and Kneafsey M (1999) Niche markets and regional speciality food products in Europe: towards a research agenda. Environment and Planning A 31, 2207-2222.

Ilbery B, Maye D, Kneafsey M, Jenkins T and Walkley C (2004) Forecasting food supply chain developments in lagging rural regions: evidence from the UK. Journal of Rural Studies 20, 331-344.

Jensen JD, Christensen T, Denver S, Ditlevsen K, Lassen J and Teuber R (2019) Heterogeneity in consumers' perceptions and demand for local (organic) food products. Food Quality and Preference 73, 255-265.

Kallas Z, Varela E, Čandek-Potokar M, Pugliese C, Cerjak M, Tomažin U, Karolyi D, Aquilani C, Vitale M and Gil JM (2019) Can innovations in traditional pork products help thriving EU untapped pig breeds? A nonhypothetical discrete choice experiment with hedonic evaluation. Meat Science 154, 75-85.

Karolyi D, Luković Z, Salajpal K, Škorput D, Vnučec I, Mahnet Ž, Klišanić V and Batorek-Lukač N (2019) Turopolje Pig (Turopoljska svinja). In Candek-Potokar M and Nieto Linan RM (eds), European Local Pig Breeds-Diversity and Performance. A Study of Project TREASURE. Rijeka: IntechOpen, pp. 1-11.

Lebret B, Kallas Z, Lenoir H, Perruchot MH, Vitale M and Oliver MO (2018) Consumers' study on traditional pork products from local breeds: expectations and hedonic evaluation. Book of Abstracts of the 69th Annual Meeting of the European Association for Animal Production Dubrovnik, Croatia. p. 492.

Lukač NB, Tomažin U, Škrlep M, Kastelic A, Poklukar $K$ and Čandek-Potokar M (2019) Krškopoljski prašič (Krškopolje Pig). In Čandek-Potokar $\mathrm{M}$ and Nieto Linan R (eds), European Local Pig Breeds-Diversity and Performance. A Study of Project TREASURE. Rijeka: IntechOpen, pp. 1-14.

Marsden T, Banks J and Bristow G (2000) Food supply chain approaches: exploring their role in rural development. Sociologia Ruralis 40, 424-438.

Mercat MJ, Lebret B, Lenoir H and Batorek-Lukač N (2019) Gascon Pig. In Čandek-Potokar M and Nieto R (eds), European Local Pig BreedsDiversity and Performance. Rijeka: IntechOpen, p. 14.

Muchnik J, Sanz Cañada J and Torres Salcido G (2008) Systèmes agroalimentaires localisés: état des recherches et perspectives. Cahiers Agricultures 17, 513-519.

Muchnik J, Cañada JS, Salcido GT, Muchnik J, Cañada JS, Torres G and Systèmes S (2020) Systèmes agroalimentaires localisés: état des recherches et perspectives To cite this version.

Nautiyal NP (2018) The sociological importance of social movements: in the perspective of Uttarakhand separate state movement. International Journal of Research in Social Sciences 8, 964-969.

Pensado-Leglise MDR and Sanz Cañada J (2018) Valorización de una Indicación Geográfica Protegida. El caso de la carne de la Sierra de Guadarrama, España. Revista Mexicana de Ciencias Pecuarias 9, 451-465.

Pugliese C, Bozzi R, Gallo M, Geraci C, Fontanesi L and Batorek-Lukač N (2019) Cinta Senese Pig. In Čandek-Potokar M and Nieto R (eds), European Local Pig Breeds-Diversity and Performance. A Study of Project TREASURE. Rijeka: IntechOpen, pp. 1-13.

Romanzin A, Corazzin M, Piasentier E and Bovolenta S (2013) Effect of rearing system (mountain pasture vs. indoor) of Simmental cows on milk composition and Montasio cheese characteristics. Journal of Dairy Research 80, 390-399.

Saaty T (1977) A scaling method for priorities in hierarchical structures. Journal of Mathematical Psychology 15, 234-281.

Saaty T (1980) The Analytic Hierarchy Process. New York: McGraw Hill.

Sanjuán AI, Resano H, Zeballos G, Sans P, Panella-Riera N, Campo MM, Khliji S, Guerrero A, Oliver MA, Sañudo C and Santolaria P (2012) Consumers' willingness to pay for beef direct sales. A regional comparison across the Pyrenees. Appetite 58, 1118-1127.

Sanz-Cañada J and Muchnik J (2016) Geographies of origin and proximity: approaches to local agro-food systems. Culture \& History Digital Journal 5, e002.

Soy-Massoni E, Monllor N, Nuss S, Markuszewska I and Tanskanen M (2019) Landscape eaters: supporting rural development and ecosystem services delivery by eating. Agriculture and Food 6, 381-398. 
Stampa E, Schipmann-Schwarze C and Hamm U (2020) Consumer perceptions, preferences, and behavior regarding pasture-raised livestock products: a review. Food Quality and Preference 82, 103872.

Swisher ME, Ruiz-Menjivar J and Koenig R (2018) Value chains in renewable and sustainable food systems. Renewable Agriculture and Food Systems 33, 1-5.

Tibau J, Torrentó N, Aguado RQ, González J, Oliver MA, Gil M and Batorek-Lukač N (2019) Negre Mallorquí (Majorcan Black) Pig. In Čandek-Potokar M and Nieto R (eds), European Local Pig Breeds-Diversity and Performance. A Study of Project TREASURE. Rijeka: IntechOpen, pp. 1-13.

Tisdell C, Eni F and Mattei E (2003) Socioeconomic causes of loss of animal genetic diversity: analysis and assessment. Ecological Economics 45, 365-376.

Varga A, Molnár Z, Biró M, Demeter L, Gellény K, Miókovics E and ... Babai D (2016) Changing year-round habitat use of extensively grazing cattle, sheep and pigs in East-Central Europe between 1940 and 2014: consequences for conservation and policy. Agriculture, Ecosystems and Environment 234, 142-153.
Vecchio R (2011) Italian and United States farmers' markets: similarities, differences and potential developments. Journal of Food Products Marketing 17, 386-406.

Vecchio R and Annunziata A (2011) The role of PDO/PGI labelling in Italian consumers' food choices. Agricultural economics review.

Vitale M, Kallas Z, Rivera-Toapanta E, Karolyi D, Cerjak M, Lebret B, Lenoir H, Pugliese C, Aquilani C, Čandek-Potokar M, Gil M and Oliver MÀ (2020) Consumers' expectations and liking of traditional and innovative pork products from European autochthonous pig breeds. Meat Science 168, 108179.

Weatherell C, Tregear A and Johanne A (2003) In search of the concerned consumer: UK public perceptions of food, farming and buying local. Journal of Rural Studies 19, 233-244.

Weible D, Christoph-Schulz I, Salamon P and Zander K (2016) Citizens' perception of modern pig production in Germany: a mixed-method research approach. British Food Journal 118, 2014-2032. 